
www.globaljournalseries.com; Email: info@globaljournalseries.com

\title{
CHALLENGES AND PROSPECTS OF THE MILLENNIUM DEVELOPMENT GOALS (MDGS) IN NIGERIA
}

\section{DONATUS E. OKON AND JOSEPH KINUABEYE UKWAYI}

(Received 13 July, 2012: Revision accepted 16, August 2012)

\begin{abstract}
The Millennium Development Goals (MDGs) is one significant break through in development policy. Nigeria's quest for sustainable development and its subsequent endorsement of the Millennium Development Goals (MDGs) in September, 2000 indicates a concerted and pragmatic attempt on the part of government and international agencies, to align with a major development agenda. A critical examination of the number of years of implementing the MDGs goals and targets by various implementing agencies - the Federal, States and Local Governments and the attendant low level of progress (based on the available MDGs progress evaluation report) adds weight to this study. The study, which is purely descriptive, indepthly assesses and examines the prospects, challenges and implications of attaining the MDGs in Nigeria, even with very few years to the target year. The specific objective of this paper is to justify the status of sustainable development in Nigeria vis-a-vis MDGs related programmes and projects. The paper notes some inherent dysfunctions and constraints on Nigeria's MDGs, and proffers useful recommendations on how some of these goals could be partially achieved - in terms of good governance, public private sector partnerships, pro-poor social policies and effective development cooperation between donor and partnering organizations and different tiers of government in the country.
\end{abstract}

KEYWORDS: UN Millennium Summit; Development Cooperation; Accountability and Transparency; Progress Reports, Human Development

\section{INTRODUCTION}

The Nigerian nation in its quests for sustainable human development has experienced and embarked upon a number of development models and strategies, some of which could rightly be seen as either dependent, exogenous and endogenous strategies (Ake 1996; Essang, 1975; Ogbuagu, 1995). One of such development models or strategies which has assumed a central place in current development studies and discourse is the World Millennium Development Goals (MDGs).

In order to have a cogent and concrete idea of what the Millennium Development Goals is all about, it is pertinent to have an insight into what development models or strategies entail.
Development strategies or models according to Potter (2008:67), is the practical steps/paths to development which may be pursued by international agencies, states in both the socalled developing and developed worlds, nongovernmental organizations, or indeed individuals, in an effort to stimulate change within nations, regions and continents. For Hettne (1995), development strategies are feasible efforts to change existing economic and social structures and institutions in order to find enduring solutions to the problems facing decision makers. Different development agenda reflect different goals and objectives. These goals reflect social, economic, political, cultural, ethical, moral and even religious influences in a particular environment.

Donatus E. Okon, Department of Sociology and Anthropology, Faculty of Social Sciences, University of Uyo, Uyo, Akwa Ibom State, Nigeria.

Joseph Kinuabeye Ukwayi, Department of Sociology, Faculty of Social Sciences, University of Calabar, Calabar, Cross River State, Nigeria. 
The Millennium Development Goals (MDGs) has been described as a catalyst for reform and social development policy in Nigeria since its inception in September 2000. The goals of the world agenda for development were adopted by the General Assembly of the United Nations on 18 September, 2000, at the UN Millennium Summit. Nearly 190 member countries of the UN have since signed up to the resolution. The Millennium Declaration which sets out the UN's vision for peace, security and disarmament, development and poverty reduction, environmental protection, human rights, democracy and good governance, the special protection of the vulnerable (that is, in particular, women, children and refugees); is also aimed at meeting the needs of Africa and strengthening the United Nations (Mair, 2005; UN, 2006; Hasan et al, 2005). The comprehensive nature of this declaration was increasingly pushed to the sidelines, however, with the so-called MDGs moving to the centre stage and thus to the heart of international debate. The MDGs were taken from paragraph 19 of a total of 32 paragraphs in the declaration and, following consultation with international organizations, were acknowledged by the UN General Assembly in 2002.

Before the emergence of the World MDGs, there has been converging agenda of welfare and human rights issues in international development into the twenty-first (21st) century. In the 1980s, the United Nations in its quests for sustainable World development (especially in the world's poor), have adopted several declarations on the rights to development, within which development itself was identified as an inalienable human right, with notions of "peoplecentred" development and "human empowerment" (UN Declarations on the Right to Development 1986 UNDP 1998; Sen 1999; Hausermann 1998; Manzo, 2003). There was a further re-affirmation of the society's obligations to respond to the inalienable rights of individuals to development and the commitment of the UN's efforts to mainstream rights-based development across the institution (Manzo, 2003).

Throughout the 1990s, agencies of the UN (such as the UNDP) have made important contributions to changing the ideas on the meanings and goals of development and in raising the understanding of the non-poor indicators of human wellbeing with the introduction of human development index (HDI), gender-related human development index (GDI) and the human poverty index (HPI). Development has been conceived in terms of human rights and freedoms; and of the recognition of the interconnectedness and multidimensional nature of the component issues. Poverty is now understood as a human rights violation, and working to ensure freedom from poverty (and its impact on human opportunity and environmental resources) worldwide in the future, is encapsulated in Millennium Development Goals, around which multi-lateral and bilateral aid are increasingly focused. Poverty Reduction Strategy Papers (PRSP) are now the framework through which eligibility for debt relief and further funding from the World Bank and the IMF is co-ordinated.

The MDGs arose from a wish, clearly expressed at the Millennium Summit; that at the turn of the Millennium, good intentions had to be matched by concrete actions. Under "values" and "principles", the UN General Assembly agreed that:

..."we believe that the central challenge we face today is to ensure that globalization becomes a positive force for all the world's people. For while, globalization offers great opportunities, at present its benefits are very unevenly shared while its costs are unevenly distributed. Only through broad and sustained efforts to create a shared future, based upon our common humanity in all its diversity, can globalization be made fully inclusive and equitable. We will spare no effort to free our fellowmen, women and children from the abject and dehumanizing conditions of extreme poverty, to which more than a billion of them are currently subjected. We are committed to making the right of development a reality to everyone and to freeing the human race from want" (http://www.un.org/millennium/ declaration/ares 552.pdf).

As described above, the MDGs include challenges for rich and poor countries alike. They set targets for developing countries to reduce poverty and hunger, and to tackle ill-health, gender inequality, lack of education, lack of access to clean water and environmental degradation. The MDGs also recognizes potential contributions from developed countries of trade, assistance and debt relief.

The accomplishments of the lofty ideals of the Millennium Development Goals in Nigeria has culminated in the formulation of various national and state governments locally initiated 
policies and programmes, all aimed at complementing the roles of the UN-funded agencies. Some of these programmes include the vision 2010, Vision 2020:20, the Yar'adua's Seven Point Agenda, the NEEDS 1 and 2; SEEDS, LEEDS; and at present, President Goodluck Jonathan's Transformation Agenda.

This paper succinctly addresses major contending issues bordering on the problems and prospects of achieving the widely acclaimed, cherished and accepted World Millennium Development Goals in Nigeria.

\section{The Problem in Context}

The Paradox inherent in this topic can best be described and illustrated by the fact that the attainment of the multi-sectoral Millennium development goals in Nigeria by the year 2015 and beyond holds the key to the rapid economic and social development of the country. Latest data from the World Bank and the IMF (2004) show that, in the fight against poverty, 50 to 60 developing countries are not on track to reach the MDGs by 2015.

The economic and social development of the world's poorest countries is perhaps the greatest challenges facing the world society at the represent time (Thirwall, 2008: 37). Over one billion of the world's over six billion population live in absolute poverty. The same number suffers from various degrees of malnutrition, and millions have no access to safe water, health care or education. This poverty is concentrated largely in countries described as "developing" and co-exists with the affluence enjoyed by the vast majority of people in countries described as "developed".

The attainment of the eight

Millennium Development Goals (MDGs), enunciated in this paper, poses a serious challenge for governments and international cooperation alike in Africa (in general) and Nigeria (in particular). The Report on Human Development from the UNDP published in 2003 and beyond, underscores that in the vast majority of countries of the emerging world (mostly Africa and Asia), the poorest sections of the population keep getting poorer. The 2007 updates further indicates that from their adoption in 2000 and the 2015 target date for the achievement of the MDGs, Sub-Saharan Africa is not on track to achieve any of the goals. However, the study noted that there have been major gains in some areas and the goals remain achievable in most African nations. More than half-way into these ambitious targets, most nations, especially in
Africa are unlikely to meet these goals unless some extra-ordinary efforts and initiatives are launched and passionately implemented.

Suffice it to say that Nigeria's commitment to the realization of the MDGs' have not been in tandem with practical aspects proposed by the United Nations Millennium Declaration adopted at the Millennium Summit held on September 2000 in New York. There are various progress reports reflecting the startling nature of the Millennium Development Goals not only in Nigeria, but in many other developing countries of the world. For most developing countries, development policy experts have variously pointed to the fact that the MDGs are ambitious, and cannot be achieved in all. They forget the fact that development is not a shortterm process, meaning that with sound socioeconomic blue-print and the co-operation of the developed countries, it would be better to achieve some (if not all) of these goals years later, than not at all.

As rightly pointed out by the United Nations Secretary-General, Ban Ki-moon,

"Looking ahead to 2015 and beyond, there is no question that we can achieve the overarching goal: we can put an end to poverty. In almost all instances, experience has demonstrated the validity of earlier agreements on the way forward. In other words, we know what to do. But it requires an unwavering, collective, long-term effort".

To further buttress the above assertion, the report released at the annual meeting of the World bank and the IMF (2011) revealed that only four African countries, namely; Cape Verde, Ethiopia, Ghana and Malawi, will likely achieve most of the Millennium Development Goals by 2015 or soon thereafter. Despite this success according to the report, serious development challenges remain in Africa, noting that "till date, more than half of Africa's population live on about less than USD 1.25 per day, while governments remained weak". And as if that was not enough, no fewer than 645 women die during pregnancy and child birth for 100,000 live births.

The recent reports from the two respected regulators of the World economy, on the MDGs (2011) have serious consequences for Nigeria. It is now clear that Nigeria has not only faltered, but failed in delivering on the laudable and people-oriented development objectives of the MDGs, even with four years to the 2015 target year. This has put into jeopardy the famously held assertions that Nigeria is Africa's 
most populous country and that the attainment of the Millennium Development Goals in Africa, depends significantly on Nigeria's success in reducing poverty. The 2011 MDGs report has it that Nigeria stands the risk of not meeting the MDGs targets in areas such as maternal and infant mortality, stressing the need for a "right political and pragmatic environment" to achieve the set target. According to it, uneven success and low human development in the country are combining among other indices, to imply that she may not be able to meet the MDGs by 2015 .

Worthy of note is the fact that despite Nigeria's great natural and human resources, which gives the country the potential to become Africa's largest economy and a major player in the global economy; the country is still poor and the level of social development is evidently limited. Most Nigerians have remained poor, still suffering from poor standard of living while social indicators place her among the least developed countries (LDCs) of the World. Available UNDP reports show further that the total poverty head count in Nigeria is astronomically on the increase with the official prevalence translating to over 100 million poor persons. Life expectancy in Nigeria in general and the geo-political zones in particular is a rude shock. As at 2010, life expectancy in the South West was 51 years; 49 years in the North-Central, North-West and South-East and 47 years in the North-East and South-South

According to the NEEDS document (2004:7), much of Nigeria's development potentials have remained untapped, putting the attainment of the MDGs by 2015 in jeopardy. 11 out of the 15 years target have just rolled by with the attendant skepticisms as to whether the goals are realizable. The debate has continued on whether Nigeria has actually done enough to take advantage of the global initiative.

Pertinent puzzling issues worth considering in this paper are:

i) do the goals and targets set by the world economic regulators reflect the real development agenda for Nigeria?

ii) how sincere have the governments been this last 11 years in leveraging on the MDGs to transform living conditions?

iii) have the development partners lived up to expectations in discharging their donor roles in a typical Nigerian economy?

iv) what are the inherent socio-political and economic constraints in the attainment of the MDGs in Nigeria? v) has there been any progress reports so far in the attainment of any of the MDGs targets in Nigeria?

vi) what hope or prospects does the country have for the achievement of the MDGs even after the target year of 2015?

Achieving these UN development goals, must be the focus of all efforts at all levels of governments - Federal, State and Local; and by stakeholders. The challenges of achieving this MDGs is a task that the architects of NEEDs and the implementers of the Transformation Agenda must face.

This paper is premised on the ground that for Nigeria to achieve the MDGs and also emerge as one of the 20 largest economies by 2020; the economy does not only require a tremendously consistent high growth rate, but a deliberate development policy fully complemented by donor agencies. The exertion of true political will, eradication of corruption and budgetary provisions for target programmes will enhance the attainment of the time-bound MDGs.

\section{Methodology}

The methodological approach to this study is purely library research. The strength of the work is updated from published progress reports and available indices of development and MDGs achievements in Nigeria.

\section{An Overview of Conceptual Issues}

The UN Millennium development declaration which could be seen as a response to the world's development challenges, commits UN member states to achieving eight (8) point goals by 2015 :

The MDGs consist of eight (8) main goals, linked to eighteen (18) targets and in turn to forty-eight (48) indicators. The highlights of the goals are as presented below:

a) Eradicate extreme Hunger and Poverty

b) Achieve Universal Primary Education

c) Promote Gender Equality and Empower Women

d) Reduce child mortality

e) Improve maternal health

f) Combat HIV/AIDS, Malaria and other diseases

g) Ensure environmental Sustainability

h) Develop a Global Partnership for Development

Soon after the above goals were set out, interests homed in on the implementation of six, 
more or less measurable sub-goals (targets) goals 4 to 6 above.

MDGs 1 concentrates on the eradication of extreme poverty and hunger; while MDGs 2-7 are related to the social and environmental dimensions.

\section{Goal 1 Eradicate Extreme Poverty and Hunger}

- $\quad$ Reduce by half the proportion of people living on less than a dollar a day

Achieve full and productive employment and decent work for all, including women and young people

\section{Goal 2 Achieve Universal Primary Education}

Ensure that all boys and girls complete a full course of primary schooling

\section{Goal 3 Promote Gender equality and Empower Women}

Eliminate gender disparity in primary and secondary education preferably by 2005 , and at all levels by 2015 .

\section{Goal 4 Reduce child Mortality}

Reduce by two-thirds the mortality rate among children under five

\section{Goal 5 Improve Maternal Health}

Reduce by three quarters $\left(3^{3} / 4\right)$ the maternal mortality ratio

Achieve by 2015 , universal access to reproductive health.

\section{Goal 6 Combat HIV/AIDS, Malaria and Other} Diseases

Halt and to reverse the spread of HIV/AIDS

Achieve by 2010 , universally accessed treatment in HIV/AIDS for all those who need it

Halt and begin to reverse the incidence of malaria and other major diseases

\section{Goal 7 Ensure Environmental Sustainability}

Integrate the principles of sustainable development into country programmes and policies, reverse loss of environmental resources;

Reduce biodiversity loss, achieving by 2010, a significant reduction in the rate of loss;
Reduce by half the proportion of people without sustainable access to safe drinking water;

Achieve significant improvement in lives of at least 100 million slum dwellers by 2020

\section{Goal 8 Develop a Global Partnership for Development}

Develop further on open trading and financial system that is rule-based, predictable and non-discriminatory, including a commitment to good governance, development and poverty reduction nationally and internationally;

Address the least developed countries "special needs". This includes tariffs and quota for access to their exports, enhanced debt-relief for heavily indebted poor countries, cancellation of official bilateral debt and more generous official development assistance (ODA) for countries committed to poverty reduction; Address the special needs of landlocked and small island developing states;

Deal comprehensively with developing countries' debt problems through national and international measures to make debt sustainable in the long term

In cooperation with the developing countries, develop decent and productive work for youth

In cooperation with pharmaceutical companies, provide access to affordable essential drugs in developing countries.

In co-operation with the private sector, make available the benefits of new technologies especially information and communication technologies (Desai and Potter, 2008: 8-10)

\section{Theoretical Approach/Paradigm}

This paper is anchored on a major development paradigm known as "Grants action strategies on development". Grant (1995) at the World Summit for Social Development stated that there is a very important need for organizations to translate words into deeds. The crucial factor in translating words into deeds has to do with planning, advocacy, sustained efforts of many within government and without, who believe in the goals, and are ready to work to achieve them. $\mathrm{He}$ further declared that the question of 
implementation, of making declarations and resolutions (such as the Millennium Development Declarations), calls for the practical ways and means to translate such larger development consensus into a larger reality.

Grant identified development action strategies which can be applied to translate words into deeds to include:

a) The breaking down of broad goals and objectives into doable and measurable propositions.

b) The securing and sustaining of the greatest possible political commitment at the highest possible political level

c) The development of expertise and resources of the United Nations and its agencies and of bilateral assistance programmes, in close support of agreed goals. This will include close monitoring of progress, followed up when necessary by increased support.

In the words of Grant, it is the doable propositions or goals that have been at the heart of development achievement; (in this case, the achievement of the Millennium Development Goals in Nigeria).

\section{Key Initiatives for Implementing MDGs in Nigeria}

Despite the kick-off of the MDGs in the year 2000 in all developing countries, key initiatives for the achievement of the Millennium Development Goals in Nigeria actually took place in 2006 when the office of the Senior Special Assistant to the President on MDGs and the Presidential Committee on the Assessment and Monitoring of MDGs were created (The Daily Sun, October 27, 2010).

At the inception of the office of MDGs, projects were executed through the Federal Government Ministries whose responsibilities synchronize with the Millennium goals objectives. Co-funding of MDGs projects with States Governments was voluntary at that time. Yet, it was obvious that if the MDGs must have the desired impact at the grassroots where poverty, hunger and diseases are highest, the states must be committed partners in the development goals.

Moreover, the activities that will be required to meet the MDGs are the constitutional responsibilities of the state governments. It then became obvious that a change in strategy was necessary to effectively involve states in order to cover more grounds and reach Nigerians at the lowest rung of the poverty ladder.

This led to what is today seen as the "Conditional Grant Scheme" (CGS). This entails a situation where states are expected to design their own interventions in a way that would most effectively have a better impact in their domains. The CGS is tied to a range of conditions to ensure good project designs and accountability of the fund being released. To get the conditional grants, the states must provide matching counterpart funding, a bank guarantee to protect the Federal fund and MOU signed. Then the application would be evaluated by a team of experts using a set of objectively agreed evaluation criteria.

To further scale MDGs activities in the states, the Federal Government introduced the CGS to the Local Government Areas to enable them fulfill their own constitutional responsibilities and by so doing accelerate the achievements of the MDGs. In the first phase of the initiative, 113 Local Government Areas were selected to participate, based on criteria approved by the National Economic Council. For the selection to take place, there must be an agreement to participate from the Local Government Chairman; the Local Government Areas must be those with significant challenges in meeting some or all of the MDGs; the population of the Local Government Area must be at a level where impact can be made, while there must also be a commitment to invest in the MDGs. This includes evidence of appropriations (in capital expenditure and associated recurrent expenditure) over the past three years, relating to MDGs - related sectors, particularly in health, education and other infrastructure.

Just like the states, the Local Government Areas working with communities will assess need and source local counterpart funding. They also draw up plans that align with achieving the MDGs.

The third key initiative is the "QUICK WINS" where the MDGs partner with the National Assembly - Senators and Representatives, collaborating with them in areas where there are guidelines for expenditure that are related to MDGs like water, health, education, etc. 
Table 1: Summary of Conditional Grants to States (2007-2009)

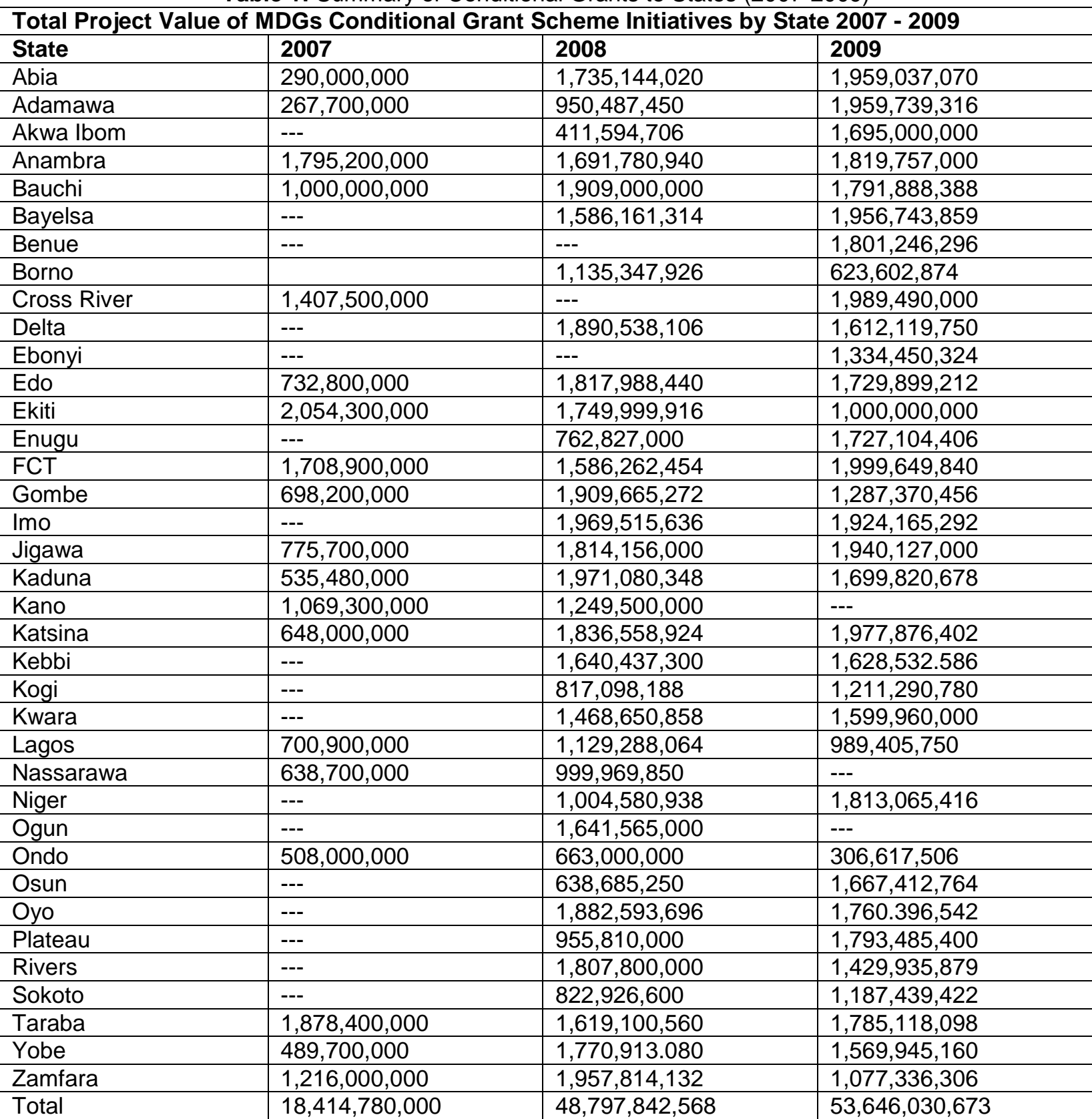

Source: Nigeria's MDGs official report 2010, released from the office of the Special Assistant on MDGs, as contained in The Daily Sun, October 27, 2010 p. 27.

\section{Assessment of Progress Towards Achievement of the MDGs in Nigeria}

Excerpts from NEED - 2 document (as presented in Table 2) below, provide some mixed results on the nation's progress towards the achievement of the Millennium Development Goals (MDGs). The table shows that on the positive side, the country has performed fairly well in the pursuit of the Universal Basic Education objective. A similar observation applies to the fight against the prevalence of HIV/AIDS among pregnant women, and success in the treatment of tuberculosis. The high point of Nigeria's good performance according to the 
document, relates to gender equality and empowerment of women.

However, not much seems to have been achieved with respect to efforts aimed at reducing extreme poverty and hunger, reduction in child mortality and maternal health, general containment of HIV/AIDS-related goals, and environmental sustainability.

Table 2: Millennium Development Goals Implementation in Nigeria

\begin{tabular}{|c|c|c|c|c|c|c|c|}
\hline $\mathbf{S} / \mathbf{N}$ & GOAL & 1990 & 1996 & 2004 & 2005 & $\begin{array}{l}\text { TARGE } \\
\text { T } 2015\end{array}$ & $\begin{array}{l}\text { PROGRESS } \\
\text { TOWARDS } \\
\text { TARGET }\end{array}$ \\
\hline 1 & $\begin{array}{l}\text { Eradicate Extreme Poverty and } \\
\text { Hunger } \\
\text { * Percentage of population living in } \\
\text { relative poverty } \\
\text { * Percentage of population living in } \\
\text { extreme poverty (consuming } 2900 \\
\text { calories or lower daily). } \\
\text { * Percentage of underweight children } \\
\text { (under five) }\end{array}$ & & & & & & \\
\hline 2. & $\begin{array}{l}\text { Achieve Universal Basic Education } \\
{ }^{*} \text { Net enrolment ratio in primary } \\
\text { education } \\
\text { * Proportion of pupils starting grade } \\
\text { one } \\
\text { who have reached grade five } \\
\text { * Grade six completion rate } \\
{ }^{*} \text { Literacy rate of } 15-24 \text { years old }\end{array}$ & & & & & & \\
\hline 3. & $\begin{array}{l}\text { Promote Gender Equality and } \\
\text { Empower Women } \\
{ }^{*} \text { Ration of girls to boys in primary } \\
\text { education (girls per } 100 \text { boys) } \\
{ }^{*} \text { Ration of girls to boys in secondary } \\
\text { education (girls per } 100 \text { boys) } \\
{ }^{*} \text { Ration of girls to boys in tertiary } \\
\text { education (girls per } 100 \text { boys). }\end{array}$ & & & & & & \\
\hline 4. & $\begin{array}{l}\text { Reduce Child Mortality } \\
\text { * Infant mortality rate (per } 1000 \text { live } \\
\text { births) } \\
\text { * Under-five mortality rate (per } 1000 \\
\text { live births) } \\
\text { * Percentage of one-year olds fully } \\
\text { minimized against measles }\end{array}$ & $\begin{array}{l}91 \\
191 \\
46\end{array}$ & & $\begin{array}{l}(2003) \\
100 \\
(2003) \\
201 \\
(2003) \\
31.4\end{array}$ & $\begin{array}{l}110 \\
\\
(2004) \\
197 \\
(2004) \\
56 \\
\text { Male: } 48.38 \\
\text { Female: } 51.62\end{array}$ & $\begin{array}{l}30.3 \\
63.7 \\
100\end{array}$ & $\begin{array}{l}\text { Worsening } \\
\text { marginal } \\
\text { improvement in } \\
2005 \\
\text { Slow } \\
\text { Slow }\end{array}$ \\
\hline 5. & $\begin{array}{l}\text { Improved Maternal health } \\
\text { * Maternal mortality rate (per } \\
1000,000 \text { live births) } \\
\text { * Proportion of births attended to by } \\
\text { skilled health personnel }\end{array}$ & 45.0 & & $\begin{array}{l}(1999) \\
704 \\
(2003) \\
36.3\end{array}$ & $\begin{array}{l}(2004) \\
800 \\
44\end{array}$ & $\begin{array}{l}>75 \\
>60\end{array}$ & $\begin{array}{l}\text { Worsening/ } \\
\text { insufficient data } \\
\text { Worsening/ } \\
\text { insufficient data }\end{array}$ \\
\hline 6. & $\begin{array}{l}\text { Combat HIV/AIDS, Malaria and Other } \\
\text { Diseases } \\
\text { * HIV prevalence among pregnant } \\
\text { women aged } 15-24 \\
\text { * Percentage of young people aged } \\
15-24 \text { reporting the use of condom } \\
\text { during sexual intercourse with a non } \\
\text { regular sexual partner }\end{array}$ & 2.2 & $\begin{array}{l}(1999) \\
5.7\end{array}$ & $\begin{array}{l}\quad(2003) \\
5.2 \\
\text { Female: } \\
\text { (2003) } \\
24.0 \\
\text { Male: }(2003)\end{array}$ & $\begin{array}{l}\quad 4.4 \\
\text { Female: } \\
\quad 39.5 \\
\text { Male: } 49.7 \\
1.97 \text { million }\end{array}$ & 100 & $\begin{array}{l}\text { Good. } \\
\text { Slow/insufficien } \\
\text { t data } \\
\text { Insufficient data }\end{array}$ \\
\hline
\end{tabular}




\begin{tabular}{|c|c|c|c|c|c|c|}
\hline & $\begin{array}{l}\text { * Number of children orphaned by } \\
\text { AIDS } \\
\text { * Prevalence and death rates } \\
\text { associated with tuberculosis } \\
\text { * Prevalence of HIV among } \\
\text { Tuberculosis patients (\%) } \\
\text { - Tuberculosis detection rate } \\
\text { - Tuberculosis treatment success } \\
\text { rate }\end{array}$ & & \begin{tabular}{l}
\multicolumn{1}{c}{46.3} \\
1.8 \\
$7.07(2004)$ \\
$1.50(2004)$ \\
$19.1(2000)$ \\
$14(2000)$ \\
$19(2000)$
\end{tabular} & $\begin{array}{l}27 \\
27 \\
80\end{array}$ & $\begin{array}{l}70 \\
85\end{array}$ & $\begin{array}{l}\text { Insufficient data } \\
\text { Worsening } \\
\text { Slow. } \\
\text { Good }\end{array}$ \\
\hline 7. & $\begin{array}{l}\text { Ensure Environmental Sustainability: } \\
\text { * Proportion of total population with } \\
\text { access to safe drinking water (\%) } \\
\text { * Proportion of people with access to } \\
\text { secure tenure (\%) } \\
\text { * Proportion of total population with } \\
\text { access to basic sanitation (\%) }\end{array}$ & $\begin{array}{l}54.0 \\
39.0\end{array}$ & $\begin{array}{l}57 \\
31.0 \\
38.0\end{array}$ & 60 & $\begin{array}{l}80 \\
100 \\
100\end{array}$ & $\begin{array}{l}\text { Slow/weak data } \\
\text { base } \\
\text { Insufficient data } \\
\text { Worsened/insuf } \\
\text { ficient data }\end{array}$ \\
\hline
\end{tabular}

Source: NEEDS - 2 document, 2004; pp. 37-40

Problems and Challenges of Achieving the Millennium Development Goals (MDGs) in Nigeria

The attainment of the Millennium Development Goals (MDGs) in Nigeria has been seriously marred by a number of factors; which has made the attainment of these goals highly impossible. A highlight is presented below:

\section{- $\quad$ Poor or Non-Implementation of MDGs- related Projects}

These are cases of poor or nonimplementation of MDGs-related community development projects by some states and local governments, even after collecting their share of the conditional grant schemes. Some of these tiers of government have not been able to access funds for MDGs projects due to non completion or abandonment of earlier projects embarked upon.

\section{- Lack of Political Will and Poor Governance:}

There is the lack of political will on the part of government in all tiers to execute and evaluate projects with effective parameters to measure achievement of each of the goals. This has to do with issues of poor governance on the part of most Nigerian leaders, who have not adopted appropriate development approaches or models to end poverty and hunger. There have been faulty responses to the issues of food security and agricultural development. Most of these inappropriate measures have really not targeted the poorest of the poor.

\section{- $\quad$ Inadequate Economic Growth}

Economic growth has been very low in Nigeria. The present rate of growth cannot sustain and stimulate investments in the private sector and human capital development; not to talk of generating full employment.

\section{Persistent High Poverty levels and Poor Human Development \\ Rather than reducing poverty levels in} Nigeria (both in states and regions) are increasing in leaps and bounds. This makes futile every poverty reduction strategies adopted as part of the Millennium Development Goals. Available human development indices cannot guarantee MDGs attainment in the country.

\section{- Politicization of MDGs - Related Project}

As is the characteristics of many developing countries, many MDGs related projects have been politicized in terms of location and usage. This does not guarantee accessibility to the supposed beneficiaries.

\section{Lack of Synergy}

There has been no coherent policy, process or institutional framework that coordinates all related activities of MDGs project implementation between the various tiers of government in the country. Though offices of Special Assistants on MDGs are established at the Federal and States levels, there is a complete lack of supervision and co-ordination in terms of MDGs project implementation. 


\section{Mismatched Expenditure on MDGs} Activities:

Too much emphasis is placed on public expenditure on the so-called MDGs-related activities, which has actually led to a wide-gap between the large public expenditure and real achievements. In most National and States budgets, there have been poor provisions for critical areas such as agriculture, health, education etc. At extreme situations, budgetary provisions do not approximate what is implemented on MDGs projects.

\section{- $\quad$ Ineffective Poverty Reduction Strategy Papers: \\ Various Poverty Reduction Strategy} Papers (PRSP) on poverty reductions are national implementation strategies. They have been developed as means of achieving some of the MDGs in the country. This has also been the pre-requisites of donor bodies for debt relief and assistance. They include the NEEDS, SEEDS and LEEDS etc. Unfortunately, the impacts of these papers have not been felt. They do not link real returns to poverty reduction and gender equality. Gender issues and the access of the rural poor to economic assets are underemphasized. They represent, to a large extent, the perception of donors about what is good for Nigeria. There is the danger of linking the PRSP to debt relief and additional resources, all of which points to mere lip service. The proportion of Nigerians living in poverty is increasing every year. Between 2004 and 2010, poverty rate in the country has risen from $54.4 \%$ to $69 \%$ involving $112,518,507$ Nigerians, but with no impact from the high GDP rates in the economy.

\section{Poor International Development Co- operation}

Donor countries, according to the Millennium Development compact owe it a duty to substantially commit significant part of their annual GDP as official assistance to the developing countries to achieve MDGs targets. Unfortunately, the flow of such Official Development Assistance (ODA) to Nigeria has rather been very small. This has similarly failed to increase on a large scale over the years, thereby constraining achievement of significant aspects of the MDGs. The World Bank has not assisted actively in canvassing for the transfer of the $0.7 \%$ of the GNP of developed nations endorsed by the United Nations as benchmark for development assistance. The level of cooperation between donor (partner) bodies and the supposed benefiting communities are at most times not complementary, as projects provided do not meet the real needs of the local people.

\section{- Infrastructural Decay}

The present state of infrastructural decay in both rural and urban areas is a serious threat for the realization of the multi-sectoral development agenda in the areas of health, education, water supply, transport, etc. This calls for reconsideration of critical issues on infrastructural renaissance in the country.

\section{- Poor Harnessing of Nigeria's Rich Human and Material Resources}

Nigeria's rich human and material resources endowment gives her the potential to become African's largest economy and a major player in the global economy. But much of these potentials have remained untapped, putting attainment of the MDGs by 2015 in jeopardy. Both governments at all levels and the private sector have not fully harnessed the available resources for sustainable development, poverty reduction and environmental development.

\section{- Poor Accountability and Corruption \\ Internal official corruption and} embezzlement (or mismanagement) of funds has been identified as greatest (combined) threat to MDGs in Nigeria because funds accessed from international donors and debt forgiveness packages do not reach their MDGs destinations, but end up in private pockets. There has equally been the problem of accountability and transparency in the delivery of MDGs projects to the people. No meaningful progress can be attained in any development programme under situation of zero-tolerance for corruption and lack of accountability. The country has a very high index rating on the international (world) corruption index. Official corruption is on the increase as those in the corridors of power have significantly abused, misused, misdirect and misapplied funds that are meant for public good. Most of the implementing agencies of the MDGs scheme have not provided detailed accounts of funds budgeted for the MDGs scheme and what has actually been achieved. Corruption has been the bane of abandonment of most MDGs projects by contractors and implementing ministries of such projects. What is seen on ground are mere sketchy paper work of achievements. Lack of transparency permeates all aspects of public 
sector management in Nigeria, which has resulted in weaknesses in the planning and budgeting process, especially for MDGs projects.

\section{- $\quad$ Lack of Quality Control}

The problems of quality control as it affect MDGs in Nigeria are issues of faulty conception, monitoring and actualization of MDGs in various states, Local Government Areas and communities. Quality control strategies should be applied in the execution of MDGs related projects. Most of the projects implemented under the MDGs are substandard, thereby putting the sustainability of the projects in jeopardy.

\section{- $\quad$ Rising Rate of Youth Employment:}

Youth unemployment rate is soaring in the country. Therefore, lack of productive employment and decent work for the large numbers of the non-working poor is a great obstacle to the efforts to achieve MDGs. Youths unemployment has risen to as much as $55 \%$, and constitute a threat to poverty reduction which is the ultimate goal of the MDGs.

\section{- Scanty and Patchy Progress Indicators \\ Progress reports on some of the} achievable MDGs in the country are not realistic. Efforts to measure areas of progress have been very problematic, due largely to lack of accurate data bank, especially in the health sector. The Slow level of progress in some of the specific targets (e.g. the health related goals) can be attributed to gaps ranging from lack of infrastructure, access to services and human resource needs.

\section{- $\quad$ Aftermath of the Global Economic Meltdown}

There are many issues in the global economic meltdown and food security crises which have severely barred the realization of the MDGs. The financial food crisis has increased the number of hungry people with real income level plummeting. Many people lost their jobs and fell back into poverty. The World food and energy crisis as well as climate change, have all complicated the realization of the MDGs in Nigeria.

Lastly, there is the lack of effective legal and cultural framework to ensure the involvement of women in all spheres of the national, political and economic life. This makes the goal of attaining gender equality and women empowerment difficult.

\section{RECOMMENDATIONS IMPLICATIONS FOR DEVELOPMENT \\ AND POLICY SUSTAINABLE}

Given the lofty and life-touching nature of the MDGs, their realization (even after the target year 2015) should be given more concern and utmost importance through pragmatic approaches. It is in realization of this that the author considers the following implementable recommendations:

There is need for full capacity development in critical sectors of the economy such as agriculture, health care, housing, urban and rural development, transportation, water supply and sanitation, etc.

Social policies that promote equality of opportunities should be implemented. Such policies should focus on:

a) equal access to good and qualitative education

b) equal access to jobs for those who can work

c) equal rights in the society for both genders

d) equal access to health facilities.

- Develop partners should always ensure that their intended projects serve the interest of the people rather than that of their parent bodies. Programmes and policies of such bodies should suit the needs and aspirations of the local people, rather than dictate what development projects should be cited for the local people. Such projects should equally be directed to key multisectoral development areas.

Issues of massive corruption and embezzlement of public funds should be pursued with more vigour in line with the UN initiatives on corruption. This will create more confidence and interests on the part of donor countries, and also make funds available for MDGs related programmes.

Governments at all tiers should ensure the proper planning and execution of peopleoriented programmes and projects. There is the need for quality and focused approaches to drive 
efficiently the demand-driven infrastructure of the local people;

In order to reduce/eradicate extreme poverty in the country, government and donor organizations should build-up effective data-bank that would enable it identify poor communities, as well as initiate measures to open the areas and give them access to social facilities and amenities.

- $\quad$ Leadership at all tiers should be focused on enough and strong political will to execute people-oriented projects.

Sound economic growth measures should be embarked upon to raise the present slow rate to about $10 \%$ and above. This will trickle down to enormous benefits for the poor.

There is the need to also properly channel expenditure to transitional reforms that would allow the intended beneficiaries have an effective voice on what the society needs to offer and the appropriate strategy for enduring maximum value from them.

It is also important to ensure that effective national development programmes relating to MDGs are demand-led and country specific; such programmes should focus on the peculiarities of the country.

- An "integrated Approach" to infrastructural development should be vigorously pursued.

- $\quad$ The Federal Government should prevail on development partners to fulfill their promises of assisting to achieve the MDGs in the country. More debts cancellation and forgiveness should be given to the country, as this will make funds available for more development.

There is the need to harness the publicprivate sector partnerships in the provision of basic needs infrastructure that will help meet some of the MDGs instead of re-treading the old path of attempting to fund increases in capacity using the public sector approach.

Improvement in achieving the universal primary education can further be realized through sustained implementation of UBE and by enhancing the capacity of the Ministry of Education.

In relation to the health based goals (Goals 4, 5 and 6), there is the urgent need to strengthen the implementation of Roll Back Malaria initiative and prevention of new diseases. The challenges of inadequate primary health care facilities, shortage of trained personnel and inadequate resource allocation need to be dealt with.

Nigerians should have mental/attitudinal change, by being optimistic about achieving success in development programmes.

\section{CONCLUSION}

As could be deduced from this presentation, the MDGs represent the UN's bold initiative to address the seeming inadequacies in global development between the South and the North; as well as achieve sustainable human and infrastructural development.

The Millennium Development Goals have the enormous potential for the sustainable development of Nigeria, as a developing country. It is worthy to conclude in this paper that while progress in the realization of the MDGs in the country has been significantly slow, a more rigorous and coherent approach and strategy can significantly achieve some of the goals. As applicable with other development models adopted in the country in past years, one cannot expect the full attainment of all the goals and targets of the Millennium declaration, given the peculiar socio-cultural, economic and political terrain of the country.

It is also important to appreciate that the MDGs are not discrete, stand-alone goals, but are inter-linked so that failure to meet one is likely to have knock-on effects for some of the other goals. This has enormous implications for a synergy and a multi-sectoral broad-based implementation approach.

Most of the MDGs intervention initiatives have only worked in small scale, which do not reach the millions of people required by the MDGs. Meeting all the MDGs by 2015 remains challenging because progress has failed to reach the most vulnerable - the poor.

Governments at all levels in the country have not shown much commitment in expending funds budgeted for the MDGs programme. Funds 
meant for MDGs have either been misappropriated or mis-applied. Many of the NGOs involved in the MDGs programme are only interested in the money they get from donor organizations. There is no transparency and accountability in the approval and disbursement of funds for MDGs projects.

\section{REFERENCES}

Ake, C., 1996. Democracy and Development in Africa. Ibadan, Nigeria: Spectrum Books.

Businessday, Wednesday, October 292008. "Facts and Figures from the 2008 MDG Report”. p. 47.

Businessday, Wednesday, October 292008. "Global Economic Showdown, others threaten MDGs Success in 2015".

Daily Sun, Wednesday, October 27, 2010 "Millennium Development Goals: Our Journey so Far". pp. 27-30.

Desai, V and Potter, R. B., (eds.) 2008. The Companion to Development Studies. (2nd ed.) London: Hodder Education.

Fresh Facts, September 26 - October 2, 2011. "MDGs: Arrested Development".

Essang, S. M., 1975. "Growth Models and Rural Development" in S. O. Olayide, et al (1975) Elements of Rural Economics. Ibadan: Ibadan University Press.

Grant, J. P., 1995. The State of the World's Children_(UNICEF Publication). Oxford University Press, New York.

Hassan, A., Patel, S and Satterth W., D., (eds.) 2005. "Meeting the Millennium Development Goals in Urban Areas" Environment and Urbanization. 17(1), Special Issue.

Hausermann, J., 1998. A Human Rights Approach to Development. London: Rights and Humanity.

Hettne, B., 1995. Development Theory and the Three Worlds: Towards an International Political Economy of Development. (2nd ed.). Harlow Longman.
Mair, S., 2005. "The Millennium Development Goals and Africa: Is Africa in Danger? Agriculture and Rural Development. 12, (2): 2005.

MDGs Office Nigeria., 2010._MDGs Report 2010 in Nigeria. Abuja, Nigeria

Monzo, K., 2003. Africa in the Right-based Approach to Development, Briefing Paper 1993(3), September. London: Overseas Development institute.

National Planning Commission., 2004. National Economic Empowerment and Development Strategy (NEEDS 2) Abuja, Nigeria: NPC

Nigerian Compass Tuesday, December 7, 2010. "Nigeria, MDGs and 2015". 47.

NPC/UNICEF., 1998. Key Social Statistics. NPC/UNICEF Nigeria.

Ogbuagu, C. S. A., 1995. Nigeria: Development Polices and Programmes. Calabar: University of Calabar Press.

Okorie, P. U., 2005. Communication Challenges of Reform Policies in Nigeria. Owerri, Nigeria: P.O. U. Ventures.

Pigg, J., 2008. "The Millennium Development Goals". In Desai, V. and Potter, R. B. (eds.) (2008). The Companion to Development Studies. (2nd ed.) UK, London: Hodder Education.

Potter, R. B., 2008. "Theories, Strategies and Ideologies of Development". in Desai, V and Potter, R. B. (eds.) The Companion to Development Studies. (2nd ed.). London: Hodder Education

Sen, A., 1999. Development as Freedom.

Thirwall, A. P., 2008. "Development and Economic Growth" in Desai, V. and Potter, R. B. (eds.) The Companion to Development Studies. (2nd ed.) London: Hodder Education.

UNDP Fact Sheet., 2005. Nigeria and Millennium Development Goals (MDGs). Lagos: Nigeria 
UNDP., 1998. Integrating Human Rights with Sustainable Human Development. New York: UNDP.

UNDP., 2000. Human Development Report: Human Rights and Human Development. New York: UNDP.

UNDP., 2001. Nigeria's Human Development Report (2000/2001) Lagos; Nigeria: UNDP Office.

UNDP., 2003. Human Development Report 2003 Millennium Development Goals: A Compact Among Nations to End Human Poverty. New York: Oxford University Press.

UN., 2006. Millennium Development Goals Report. New York: United Nations.

The Guardian, Tuesday, November 10 2009. “UN Economic Crises Threatens MDGs Targets in Africa, Says Migro" p. 34.

The Guardian, Tuesday, November 19, 2010. "Governor Tasks Development Partners on MDGs Targets"

The Guardian, Wednesday, October 26, 2011. "Why Nigeria may not meet MDGs, by UNDP", 3

The Millennium Development Goals: Progress Chart (2005) http://www.un.org/ millenniumgoals/mdg_chart_sept.pdf.

The Nation, Monday, September 6, 2010. "Accountability Will Ensure MDGs Success". 8.

The Nation on Sunday, November 7, 2010. "Why Hunger May not end in 2015".

The Nation, Tuesday, November 8, 2011. "Development Partners Score Nigeria Low on Growth Indices". Pp. 2-3.

The Nation, Wednesday, October 26, 2011. "Niger State Expends N3b on MDGs Projects"

The Punch, Thursday, November 4, 2010. "Assessment of Progress on MDGs Problematic - FG".
The Punch, Friday November 11, 2011. "Nigeria's Low Scores in Human Development", p. 18

The Punch, Tuesday, November 29, 2011. "Adopting Human Rights Based Approach to Development. p. 16

The Sunday Sun, December 5, 2010. "Planning, Key to Attaining MDGs" - Obi

The Sunday Punch, December 19, 2010. "Nigeria Requires US\$44.56bn to meet MDGs in Agric".

The Weekend Pioneer, Friday, September 30, 2011. "AK Govt. Re-states MDGs Commitment". 18. 